\title{
The Uniqueness and Idiosyncrasy of Sustainability of Kelantan Political
}

\author{
Heri Kusmanto $^{1}$, Mustafa Ahmad ${ }^{2}$, Warjio $^{3}$ \& Agung Suharyanto \\ ${ }^{1,3}$ Department of Political Science, Faculty of Social and Political Sciences, \\ Universitas Sumatera Utara, Medan, Indonesia. \\ 2 Partai Amanah Negara, Kelantan, Malaysia \\ ${ }^{4}$ Public Administration Study Program, Faculty of Social and Political Sciences \\ Universitas Medan Area, Medan, Indonesia.

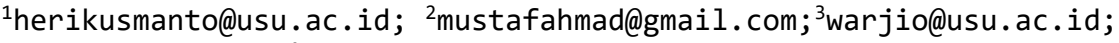 \\ ${ }^{4}$ agungsuharyanto@staff.uma.ac.id
}

\begin{abstract}
Politically, Kelantan is unique compared toother statesin Malaysia. Manifestations of the doctrine of competition between UMNOand PAS occurred in this last fortress of the Malay states (the last bastions of Malayness). Different political doctrines has caused relations between PAS-led Kelantan State Government and Federal Government, the UMNO-led Alliance,is always hot. But the doctrine of competition began to simmer down, upon the occurrence of the May 13, 1969 event, which allows both partiesto come up with a government known as the PAS-Alliance Coalition Government (1973-1974) and laterto be replaced by the Barisan Nasional (National Front) Governmentin 1974. PAS positionin the National Frontonly lasted for threeand a half years, when a political turn oil brewed up and has caused the party'sexpulsion. The expulsionof PAS from the National Front has caused the defeat of PAS to lose Kelantan State Legislative Assembly in the 1978 General Election. This provides the opportunity tothe UMNO-led Barisan Nasionalto rule Kelantan for 12 years and engage itself in extensive political strategies to defend its position from being constantly attacks by the PAS opposition quarters. However, due to some internal and external problems in the UMNO, PAS has won back the administration of the state of Kelantan by winning State Legislative Assemblyin the 1990 general election.
\end{abstract}

Keywords: Politics, Kelantan, Parti Islam SeMalaysia, United Malays National Organisation and National Front.

\section{INTRODUCTION}

In Malaysian politics, Kelantan is considered as "The Sum of Malaysian Politics". The statement is said by Yang DipertuanAgungParti Islam SeMalaysia (PAS) Pusat, MohdAsri bin Haji Mudadalam in his special announcement of the $4^{\text {th }}$ Anniversary of PAS which took place on the $4^{\text {th }}$ December 1977. In these remarks, MohdAsri bin Haji Muda stated about Kelantan's political upheaval which was in force at the time as follows: 
Kelantan, the last bastion of Malayness was also the only country that became the main field of manifestation of political competition among UMNO which was the parent party to the Parties of the Association (1953-1974) and dominated the National Front (1974-present) and the main rival or competitor is the Pas who ruled Kelantan after the party won the 1959 General Election Options by being caught by surprise. The two parties that had opposing characteristics made the Kelantan state an arena for political competition in an effort to expand or widen their influence each among the people of the country. Kelantan is also the political and religious orthodox center of Malaysia's leading UMNO and PAS coalition involving religion, creed, ideology, policy, ideals, struggles, goals and philosophies of different struggles, between UMNO and PAS has also caused ShamsulAmri [1] to claim that Kelantan is an "enfant terrible" state in the process of forming a political state of Malaysia that has been under siege since the arrival of European powers in Malaya and continues to this day.

The impression is that in the past half century, it was common to witness that Kelantan people had exchanged their government three times. Even though those who took over the government consisted of two Malay parties who came from different perspectives and political ideologies, in essence the Kelantan people n not conservative accepting government dogma something political party only [2].

\section{METHOD}

The writing of this manuscript is based on research on re-reading of journals, theses and dissertations that write (review) about the dispute between the two parties namely the United Malays National Organization (UMNO) parties and the Islamic Party of Malaysia (PAS) in Kelantan, Malaysia. This writing was driven by the fact that competition between the two parties, namely the United Malays National Organization (UMNO) and the Malaysian Islamic Party (PAS), continued throughout Kelantan's history. The doctrinal competition has led to the relationship between the Kelantan Kingdom, the leadership of PAS, and the United Kingdom's leadership of the Alliance, especially the UMNO, which was always hot. In order to write about themes that are considered 'sensitive' but crucially must be answered, then rereading the manuscripts in the form of ethnographic travel journals, journals, theses or dissertations.

The main text used as a reference in this manuscript comes from the text Emerson (1960) about studies of Malaysia. Skeat (1953), about the history of the Malaysian Kingdoms expedition from 1892-1900. Roff (1974), about Kelantan in terms of religion, social and politics in the Kingdom of Malaysia. Yusoff (1995) concerning socio-political developments and changes in Kelantan in 1955-1995. Rahman (1988), concerning Background and Early History of Duff Syndrome in Kelantan in 1900-1905. Ismail (1978), a Kelantan political analysis as a political and government event.

\section{RESULT AND DISCUSSION}

\subsection{Competition of UMNO-PAS in Kelantan Politics}

At the same time, the interesting factor in modern politics in Kelantan is the sensitivity and activism of the people [3]. Elections in Kelantan are often warm and among the highest 
compared to other states in the Federation of Malaysia [4]. in Kelantan, with more than 95 percent of its Malay voters, it resembles the clash of the two largest Malay parties, UMNO and PAS, both of which are led by Muslim leaders. Many voters in Kelantan have strong voting power, because they are not willing to change government if that is the will or demand of contemporary politics [5].

The rivalry between the two parties had been prolonged since the May 13, 1969 incident, when the idea of a Mixed Government between the two parties was first realized on January 1, 1973 by the Prime Minister of Malaysia and UMNO President Tun Abdul Razak bin Hussein and the Chief Minister. Kelantan comprises PAS Chief Executive MohdAsri bin Muda [6]. The idea of the PAS-Alliance Alliance Government on January 1, 1973 and later the Barisan Nasional on July 1, 1973, has led the people of Kelantan together for four years under the auspices of the joint struggle, indirectly reducing "politicizing" among the Malay community in Kelantan in particular, and Malaysia in general [7].

The UMNO and PAS political rivalries had subsided, following the May 13, 1969 incident, when the idea of a Mixed Government between the two parties was first realized in 1973 by the Prime Minister of Malaysia and UMNO President Tun Abdul Razak Hussein and the MenteriBesar Kelantan and the PAS President [8]. The idea of a PAS-Alliance coalition and later the Barisan Nasional led the Kelantanese community for four years under the arm of the coalition, indirectly reducing politicization among the Malay community in Kelantan in particular, and Malaysia in general.

The success of Tun Abdul Razak bin Hussien influenced PAS to join the PAS-Alliance Alliance Government in 1973 and later the Barisan Nasional Government in 1973, though widely acknowledged and accepted, but has provoked jealousy among UMNO Special Forces and Barisan Nasional veterans. [9]. Among these leaders were Senu Abdul Rahman, Khir Johari, Syed JaafarAlbar, Harun Idris, TunDatu Mustapha Datu Harun, Political Secretary to Tun Abdul Razak, Abdullah Ahmad, and Kelantan UMNO Relations Chairman TengkuRazaleighHamzah, who is known as the "blue-eyed boy" of Tun Abdul Razak Hussein [10]. His ally RazaleighHamzah, who is rising in the UMNO leadership hierarchy, is said to be less inclined to join the PAS-Alliance Alliance and later the Barisan Nasional Government in Kelantan from the beginning. This is because he has the confidence that UMNO is capable of capturing Kelantan through Ray's election a General 1974 and the idea of a PAS-Alliance Mixed Governance and later, the Barisan Nasional Government narrowed its opportunity to advance in the political leadership hierarchy of the nation's political system [11].

However, due to the idea of forming the Alliance-PAS Mixed Government and later the Barisan Nasional Government as part of the political strategy of Tun Abdul Razak Hussein and MohdAsriMuda, he was forced to accept the presence of the Alliance-PAS Mixed Government and later the Barisan Nasional Government, thus eliminating the opportunity This is in view of the fact that PAS is the dominant ally in the political structure of the Barisan Nasional Government in Kelantan, when the post of Chief Minister, Deputy Chief Minister and some of the State Assembly Members are held by members of the state assembly [12].

Although Kelantan's UMNO opportunities and efforts have been stoked to take over the country, the party has come up with a political strategy by nominating and lobbying Member of the Legislative Assembly, Mohammad bin Nasir as Kelantan MenteriBesar to replace Isaac Lutfi Omar [13]. The election of Mohammad bin Nasir who is considered to be honest, gracious and straightforward as the Chief Minister is on the matter of the Sultan of 
Kelantan, TuankuYahaya Petra Ibni Al-Mahrum Sultan Ibrahim and is endorsed by Tun Abdul Razak Hussein, the Prime Minister of Malaysia and the President of the Barisan Nasional. Sungai Rasau State Assemblyman Wan Ismail bin Wan Ibrahim [14], who has a high school diploma in literature from the University of Malaya and the Barrister of Law from the University of London as Kelantan MenteriBesar, eventually had to relinquish the post of MenteriBesar Kelantan.

Kelantan PAS leadership recognizes that the appointment of Mohammad bin Nasir as MenteriBesar Kelantan is a long-term UMNO political strategy to undermine the Kelantan PAS which has been the party's governing body in Malaysian politics. Further, the Kelantan PAS leadership has also seen the appointment of Mohammad bin Nasir as The long-term strategy of Kelantan UMNO liaison chairperson TengkuRazaleighHamzah to enhance his popularity in Malaysian politics 1964 [15]. However, the Kelantan PAS leadership could not prevent the development, as it was tied to the concept of the Barisan Nasional concept.

Symptoms of a dispute between UMNO and PAS in the Barisan Nasional Government began to appear sharply after the death of Malaysian Prime Minister Tun Abdul Razak in 1976. The disagreement arose as PAS was said to have taken advantage of Barisan Nasional's efforts to expand its influence among the Malays. This is evident, when MohdAsriMuda used his post as Minister of Land and Regional Development to give many seats in the Federal Land Development Authority (FELDA) to members of the party. Asri bin Hajj Young was seen as a success, when the Federal Land Development Authority (FELDA) became the "stronghold" of PAS. This has led to dissatisfaction among UMNO leaders [16].

The motion passed to Mohammad Nasir by the Provincial Assemblyman Hussin Abdullah and supported by Pasir Mas District Assemblyman Hashim Omar in the Kelantan State Assembly sitting on October 10, 1977 was passed with 20 votes and 16 votes. The protest sparked a protest of "80,000 people" led by Ibrahim bin Ali on the morning of September 24, 1977. Demonstrators in support of MenteriBesar Kelantan Mohammad bin Nasir have acted wildly by throwing stones at shops, burning tires, raiding State Assembly and Secretary of State (SUK) buildings and forcing the Polis Simpanan Persekutuan (FRU) and Polis PencegahRasuhan (PORU) to release tear gas to disperse the rioters. issued a 24-hour curfew covering certain areas within the Bharu Police District [17].

In restoring peace in Kelantan, Prime Minister of Malaysia Hussein Onn took the opportunity by presenting the Emergency Powers Bill 1977 in the House of Representatives on November 8, 1977, at 3:00 pm [18]. Proposed Kelantan Emergency Power Bill 1977 was passed with 118 votes in favor and 18 against. The opposition of the 11 SeMalaysia Islamic Party (PAS) MPs to the Bill resulted in the removal of the Parti Islam SeMalaysia (PAS) from the Barisan Nasional coalition under Article 14 of the National Constitution. The removal was made on the grounds that Parti Islam SeMalaysia (PAS) refused to support the Kelantan Emergency Bill to put Kelantan under the control of the National Movement Council (MAGERAN) for 96 days with the administration of the State Government Directorate directly responsible to the Prime Minister's Department in Kuala Lumpur under the Emergency Powers Act (Kelantan), 1977, Section 4.

When MajlisGerakan Negara (MAGERAN) was revoked or dissolved [19], a Kelantan State Assembly election was held on March 11, 1978. Elections held separately from the 1978 General Elections saw PAS losing the state of Kelantan which is said to be the "pillar of the line" to the struggle when the party suffered its worst defeat, having just won two state 
Assembly seats (DUN) Sering and ManekUrai. The defeat has forced PAS to hand over UMNO led by TengkuRazaleighHamzah.

\subsection{KerajaanBarisan Nasional Pimpinan UMNO (1978-1990)}

Establishment of KerajaanBarisan Nasional-BERJASA after the Kelantan State Assembly Elections 1978, it provided the State Assembly, Mohammad Yaacob as Kelantan MenteriBesar, and State Legislative Assembly Member Hussein bin Ahmad as Kelantan Deputy Chief Minister [20]. However, the administration of Mohammad Yaacob as MenteriBesar Kelantan was overshadowed by the charismatic leadership of TengkuRazaleighHamzah who was regarded as the true determinant of Barisan Nasional Kelantan government politics. Barisan Nasional Kelantan [21]. This disintegration has caused the Kelantan National Government's politics to deteriorate as Mohamad bin Yaacob's leadership lacked direct charismatic leadership to win the hearts and minds of the Kelantan people.

Although General Election in 1986 saw the Barisan Nasional government maintain its dominance in Kelantan, it was the political life of the Kelantan government led by Mohamad bin Yaacob in the most serious internal affairs, when TengkuRazaleigh bin Hamzah opposed Tun Dr. Mahathir bin Mohamad in the UMNO Malaysian presidential race in 1987. TengkuRazaleigh's narrow defeat with 43 votes [22] saw Kumpulan 12, which then became Kumpulan 11, summoned TunDr's victory. Mahathir Mohamad was next seen in UMNO's sentence by Kuala Lumpur High Court Judge Harun Mahmud Hashim on February 2, 1988.

The establishment of UMNO (New) by Tun Dr. Mahathir Mohamad ousted TengkuRazaleighHamzah and led him to establish the $46^{\text {th }}$ Party in support of political life in the country's politics. The General Assembly 1990.However, the removal of TengkuRazaleigh bin Hamzah from the Kelantan political party has caused the Kelantan UMNO to look weak especially in terms of its leadership. TengkuRazaleighHamzah's defeat on April 24, 1987 to Tun Dr. Mahathir bin Mohamad with a majority of 43 votes has led to UMNO's ban by the Kuala Lumpur High Court. The 1990 General Election, which took place on October 21, 1990, created a new history in the country's politics, sweeping all parliamentary seats and the state assembly at the same time leading Kerajaan Barisan Nasional pimpinan UMNO.

\section{CONCLUSION}

This article aims to determine the uniqueness of the Kelantan in terms of politics, competition between United Malays National Organization (UMNO) parties and the Partai Islam SeMalaysia (PAS). The research method used was a literature study or literature study to determine the competition between the two parties in Kelantan. The results of the study found that the competition had caused the relationship between the Kelantan, the leadership of PAS, and the United Kingdom's leadership of the Alliance, especially UMNO, which was always hot. The PAS position in the National Front was only able to last for three and a half years because of the political turmoil that caused it to be removed. The removal caused PAS to lose power to lead Kelantan, especially after suffering defeat in the General Election Choice of the Kelantan State Invitation Board 1978. This gave the National Barisan an opportunity to be lead by UMNO and govern Kelantan for 12 years by carrying out political strategies to maintain his position from the insistence of PAS. But there are some factors that occur in the 
Barisan Nasional especially UMNO that caused Kelantan to be governed by PAS through the 1990 Greater Public Choice.

\section{REFERENCES}

[1]. S.A. Baharuddin. Kelantan Dalam Proses PembentukanBangsa Malaysia: SebuahCatatanAnalitikal. dlm. Mohammad AgusYusoff. Perkembangan dan Perubahan Sosio-Politik Kelantan 1955-1995. Bangi: Falkuti Sains Kemasyarakatan dan Kemanusiaan, Universiti Kebangsaan Malaysia.1995.

[2]. M.S. Omar. Tuanku Ismail Petra:idealisme\&keprihatinankepadaagama, bangsa dan negara. Kota Bharu:PerbadananMuzium Kelantan. 1995.

[3]. M. Ahmad. KepimpinanTengkuRazaleighHamzahdalampolitik Kelantan. Bangi: Program Sejarah, SainsPolitikdanStrategi, UniversitiKebangsaan Malaysia.2009.

[4]. KementerianPenerangan Malaysia. Kearahperpaduankebangsaan. Kuala Lumpur: JabatanPenerangan Malaysia. 1974.

[5]. M.A.H. Muda. UcapanpembukaanRasmiKongres Khas PAS MengenaiKerajaanCampuran. Kuala Lumpur:Penerbit PAS Pusat.1972.

[6]. A. Mohamed. Perebutankuasadalam UMNO 1975-1976. Mingguan Dialog: 21 Julai.2002.

[7]. Surat TimbalanMenteriKementerianSains, TeknologidanAlamSekitar, Abdullah bin Ahmad kepadaPerdanaMenteri Malaysia, Y.A.B. Datuk Hussein bin Onn bertarikh 5 Oktober 1976.

[8]. M. Ahmad. KepimpinanTengkuRazaleighHamzahdalampolitik Kelantan. Bangi: Program Sejarah, SainsPolitikdanStrategi, UniversitiKebangsaan Malaysia.2009.

[9]. M.A. Kamarudin. PenaungandalamkepemimpinanpolitikMelayu: UMNO Kelantan 1946-1990. Universiti Malaya.1998.

[10]. LaporanBadanPerhubungan Pas Negeri Kelantan untukKongres PAS Ke-XXI di Kuala Lumpur padaJulai 1975.

[11]. SulitButir-ButirMengenai Wakil Rakyat/ Ahli DewanUndanganNegeri/ Senator-Senator olehJabatanPenerangan Malaysia. TT.

[12]. Surat "Orang PAS Tulen" kepadaTimbalanPersuruhjayaBadanPerhubungan PAS Kelantan, KhaidirKhatib, PersuruhjayaBadanPerhubungan PAS Kelantan, Nik Abdul Aziz Nik Mat dan Yang DipertuaAgung PAS, MohdAsri Haji Muda (tidakbertarikhdantidakbertajuk). hlm 1 .

[13]. M. Ahmad. KepimpinanTengkuRazaleighHamzahdalampolitik Kelantan. Bangi: Program Sejarah, SainsPolitikdanStrategi, UniversitiKebangsaan Malaysia.2009.

[14]. A. Mohamed. 2002. Perebutankuasadalam UMNO 1975-1976. Mingguan Dialog: 21 Julai. 2002.

[15]. DrafkertaskerjaPegawaiPenyelidikan UMNO Malaysia, Wan MohdMahyidin bin Wan Nawangbertajuk "PAS MerugikanPerjuanganBangsabertarikh 31 Mac 1969. Hlm. 7.

[16]. Warta KerajaanNegeri Kelantan. 10 November; Utusan Malaysia. 23 Oktober1977..

[17]. PenyataRasmiParlimen, Dewan Rakyat ParlimenKeempat. PenggalKetiga. Jil. 111. Bil. 37, Hari Selasa, 8 November 1977. Hlm. 4119-4120.

[18]. Utusan Malaysia. 4 Februari 1978.

[19]. Warta Kerajaan Kelantan. 20 March 1978.

[20]. Kepimpinan Tengku Razaleigh bin Hamzah di Kelantan mulai dipertikaikan melalui rencana Chamil Wariya dalam Utusan Malaysia pada 26 Julai 1984 yang berjudul: 
"Ketua Perhubungan UMNO Kelantan: Ramai Mahukan Perubahan Tapi Takut Bersuara".

[21]. Keputusanpertandingan Ahli MajlisTertinggi UMNO Malaysia bagitahun 1987/1990.

[22]. M. Ahmad. KepimpinanTengkuRazaleighHamzahdalampolitik Kelantan. Bangi: Program Sejarah, SainsPolitikdanStrategi, UniversitiKebangsaan Malaysia. 2009. 